\title{
Assessment of the ecological status of the rivers of the city of Douala from Macrophyte communities: Case of Kondi and Tongo Bassa
}

\author{
Nwamo RD ${ }^{1,}{ }^{*}$, Ndjouondo GP 2 and Dibong SD ${ }^{3}$ \\ ${ }^{1}$ Department of Management of Aquatic Ecosystems, Institute of Fisheries and Aquatic Sciences in Yabassi, University of \\ Douala, P.O. Box 7236, Douala, Cameroon. \\ 2 Department of Biology, Higher Teacher Training College, University of Bamenda, P.O. Box 39 Bambili, Cameroon. \\ ${ }^{3}$ Department of Botany, Faculty of Science, University of Douala, P.O. Box 24157 Douala, Cameroon.
}

GSC Biological and Pharmaceutical Sciences, 2021, 15(02), 015-028

Publication history: Received on 01 February 2021; revised on 23 April 2021; accepted on 25 April 2021

Article DOI: https://doi.org/10.30574/gscbps.2021.15.2.0068

\begin{abstract}
Observations made in rivers of Douala showed that aquatic ecosystems receive little attention in terms of their environmental monitoring. The aim of this study was to assess the ecological status of Kondi and Tongo Bassa rivers at from their communities of macrophytes. Specifically, it was question to evaluate the physicochemestry environment of these rivers as well as the diversity of the macrophyte species. Then, the physicochemestry parameters were measured (about $50 \mathrm{~cm}$ deep) between $08 \mathrm{am}$ and $11 \mathrm{am}$. Concerning characterization of macrophytes, 03 transects of $400 \mathrm{~m}$ length each were materialized. Then, 201 quadrats of $1 \mathrm{~m}^{2}$ were realised to make a specific and quantitative inventory. The listed species were assigned an Abundance-dominance coefficient. Then, the diversity and resemblance indices, the abundance index, the average recovery, the Shannon index and the Piélou equitability index, the Sorensen similarity coefficient, the Shannon index and the Piélou equitability index were analysed. According to results, ammonia, orthophosphates and nitrates particularly influence the distribution of macrophytes in the Kondi and the Tongo Bassa rivers. These parameters show that the water include high organic matter loads indicating organic pollution. In addition, the plant communities encountered in these rivers were relatively rich, diversify and distributed according to a decreasing gradation of mineralization and trophy. Also, the Piélou index in these rivers was generally below 0.55 reflecting poorly diversified waters. Finally, the structure of the macrophyte reveals that it was generally dominated by a few species, including the Poaceae particulary Pennisetum purpureum species, characteristic of eutrophic environments.
\end{abstract}

Keywords: Ecological status; Kondi; Tongo Bassa; physicochemestry parameters; Macrophytes

\section{Introduction}

The demographic growth of the population is accompanied by an equivalent need of subsistence elements, particularly water. However, during the World Summit on Sustainable Development (WSSD) held in Johannesburg in 2002, the gradual depletion of available water resources was an overall observation. This situation is due to the fact that inland waters attract and concentrate many populations for their activities. This situation lead to a deterioration which results from punctual and diffuse pollution, the modification of the physical and chemical characteristics, and the exploitation of cultivable land surfaces due to the intensification agricultural activities and rampant urbanization [1]. They thus negatively influence not only the ecological quality of the hydro-system, but also biological communities in general ([1]; [2]). Anthropogenic actions therefore have negative consequences on the health of rivers. However, it is known that monitoring of water quality has long been based on physical and chemical analysis in order to reveal pollution [3].

\footnotetext{
* Corresponding author: Nwamo R.D

Department of Management of Aquatic Ecosystems, Institute of Fisheries and Aquatic Sciences in Yabassi, University of Douala, P.O. Box 7236, Douala.
}

Copyright (C) 2021 Author(s) retain the copyright of this article. This article is published under the terms of the Creative Commons Attribution Liscense 4.0. 
However, these analysis show some shortcomings insofar as they reflect the image of the environment at the time of sampling and do not provide information on the effect of toxic substances on the health of the communities present [4]. Because of their significant capacity to respond to environmental changes, primary producers have long been used as biological indicators of the quality of aquatic environments [5]. This is the case with macrophytes; certain parameters measured on macrophyte communities make it possible to develop indicators of the quality of the environment according to the types of disturbance caused by human activities (eutrophication, chemical contamination, etc). Cameroon is home to several rivers of great interest in view of the many potentials they present (for hydroelectricity, irrigation, agriculture, livestock, fishing and ecotourism and water supply) [6]. However, observations made in many cities, notably in Douala, show that the state of these aquatic ecosystems into which waste water is discharged from the various dumps of industries, agglomerations and even from the leaching of the surrounding land, is fairly demonstrative of the impact of human action. Given the role played by watercourses, this observation probably constitutes the first symptoms of the "bad" state of an ecosystem. However, despite this importance and the intensity of the threats they face [7] we therefore understand the urgency of studying these ecosystems to understand their functioning with a view to sustainable management of the resource [8]. In addition, to this point of view, ecosystems of flowing water receive very little attention as to their environmental assessment and their follow-up. It becomes important to monitor the quality of these waters. The major challenge lies in the search of methods that would make it possible to easily assess the quality of watercourses by assessing the potential of primary producers using macrophytes as biological markers for the disturbance of aquatic ecosystems, notably the Kondi and Tongo Bassa rivers in Douala. In addition, in Cameroon, studies designed in determining the quality of water from the structure of bacterilogical, macrophytic and phytplanctonic communities have been carried out in several rivers ([9]; [10]; [11]). Overall, this work highlights the sensitivity of certain species to the physical and chemical environment of the rivers studied, most often due to organic pollution of anthropogenic origins. To our knowledge, none of these studies have used macrophytes as an indicator of water quality in the Kondi and Tongo Bassa rivers. The general objective of this work was to assess the ecological state of the Kondi and Tongo Bassa rivers in the city of Douala base on their communities of macrophytes combined with the quality of water. Specifically, it means evaluating the physical and chemical environment of the rivers studied as well as the diversity of the macrophyte species present in the rivers at that particular time.

\section{Material and methods}

\subsection{Location of the study area}

The study was carried out in the city of Douala, a city characterized by the presence of a mangrove with mangroves stands and raffia in the marshy lowlands. This zone has beared important anthropogenic activities for many years and has been transformed deeply into plantations and residential areas. In addition, the rivers studied serve as dumping grounds for local populations and thus receive various organic and inorganic wastes likely to modify the ecology of these environments. Unfortunately, these watercourses are not monitored by the municipalities.The Kondi is located between latitude $04^{\circ} 01^{\prime} 87$ 'and $04^{\circ} 04^{\prime} 18^{\prime}$ north and between longitude $09^{\circ} 45^{\prime} 78$ 'and $09^{\circ} 46^{\prime} 89^{\prime}$ east, with a length of approximately $5.9 \mathrm{~km}$ and an area of approximately $10.375 \mathrm{~km}^{2}$ [12]. Tongo Bassa is located between latitude $04{ }^{\circ}$ $02^{\prime} 44^{\prime \prime}$ and $04^{\circ} 04^{\prime} 23^{\prime \prime}$ north and between longitude $09^{\circ} 43^{\prime} 43^{\prime \prime}$ and $09^{\circ} 44^{\prime} 05^{\prime \prime}$ east and has a length of about $6 \mathrm{~km}$. It has its source in Ndogbati, and water the BP Cité, Sic Cacao, Makèpè Missokè, Makèpè Maturité, Bépanda Petit Marché, and Bépanda Yonyong neighborhoods. In this study, three stations were chosen on each of the rivers. For the Kondi, the first two stations K1 and K2 frame the portion of the Kondi receiving the effluents from the Ndokoti industrial zone. Regarding station K3, it is located in a marshy area rich in several species of macrophytes including Pennisetum purpureum, Echinocloa pyramidalis and Paspalum conjugatum often used as wastewater treatment plants in Yaoundé. Concerning the Tongo Bassa, along its area of approximately $10.375 \mathrm{~km}^{2}$, the first two sampling stations, T1 and T2 frame the portion of Tongo Bassa which receives the effluents from neighboring dwellers, in particular Bénédicte College and BP City. Station T3, is located downstream and covers the marshy area that links Tongo Bassa to the Ngongué river that is one of its main tributary (Fig.1). 


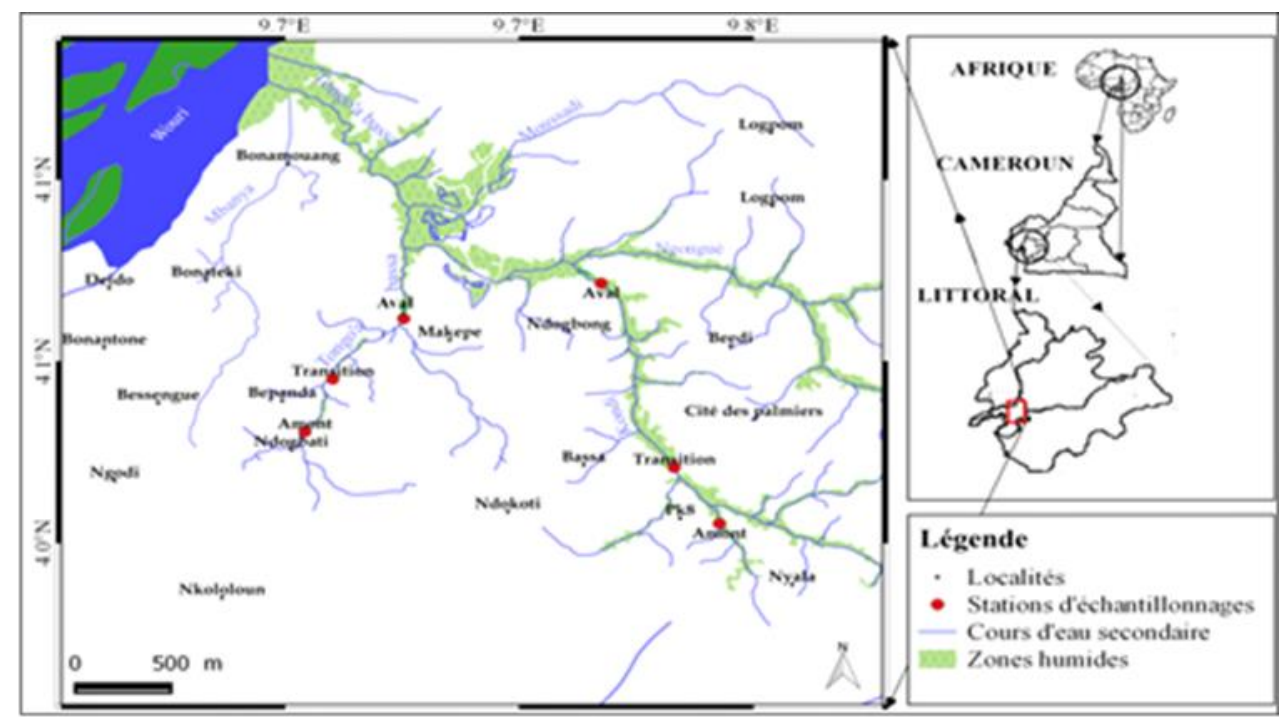

Figure 1 Map of presentation of Kondi and Tongo Bassa river, Map with a scale of 1/50000

\subsection{Methods}

For practical implementation, seasonal development and accessibility, the scientific team agreed to carry out two hydrobiological missions at the end of the dry season, more precisely in December 2014 and December 2015. [13] and [5] structured the same strategy on the basis of the seasonal distribution in Lake Taabo in Ivory Coast and on the Aquitaine water bodies in France.

\subsubsection{Characterization of the physico-chemical environment}

At each station, the physical and chemical parameters were measured at the surface, about $50 \mathrm{~cm}$ deep between 08:00 and 11:00 am. In the field, a multi-parameter of brand HORIBA U53 was used to measure pH, water temperature, conductivity, turbidity, optical density, dissolved solids, ammonia, iron and chlorine content, that permitted to evaluate the values of certain physical and chemical parameters of the water. All measurements were made in triplicates. For the measurement of the nitrates and $\mathrm{BOD}_{5}$ content, the water samples intended for the laboratory analysis were sample in polyethylene bottles of $1000 \mathrm{ml}$. These samples were taken against the direction of flow, without making bubbles, without trapping air inside and the bottles were filled to brim. The samples were then closed, kept in a cooler before being transported into the laboratory where analysis were carried out. Transparency was measured with a Secchi disc. According to the longitudinal gradient, the depth expressed in meters was measured using a graduated rod. The operation was repeated 03 times at distances of approximately 50 meters apart. Current speed, on the other hand, was measured using a stopwatch that allowed time to be taken and a floating object over a distance of 10 meters. The formula $\mathrm{V}=\mathrm{d} / \mathrm{t}$ with $(\mathrm{V}=$ speed in $\mathrm{m} / \mathrm{s}, \mathrm{d}=$ distance traveled in $\mathrm{m}$ and $\mathrm{t}=$ time in seconds) made it possible to calculate the water speed and the Berg scale (1948) was used as a reference to qualify the current velocities. PH has been used as a measure of the acidity or alkalinity of water on a $\mathrm{pH}$ scale. The conductivity values, which provide information on the salinity of the soil and water, were classified on the [14].

\subsubsection{Characterization of macrophytes}

In each sampling station, macrophytes were sampled by materializing the surveys using the linear transect method. Three transects of $400 \mathrm{~m}$ length each were materialized. Then, 201 quadrats of $1 \mathrm{~m}^{2}$ crossing the median line of each transect made it possible to make a specific and quantitative inventory of the species. After materialization of transects, the listed species were assigned an Abundance-dominance coefficient corresponding to the percentage of spatial overlap of each one. After harvesting unidentified species, care were taken to facilitate the identification of species whose scientific names were not known in the field. Then all the species names were sorted in a table. Taxonomic richness (S) is the number of distinct taxa present in a sample. In this work, macrophytes have been identified up to the rank of the species. Also, the diversity and resemblance indices, the abundance index, the average recovery, the Shannon index, the Sorensen similarity coefficient, the percentage of occurrence and for the qualitative analysis of phytoplankton, the Shannon index and the Piélou equitability index were determined. The collection of specific recoveries was done as a percentage of the total recovery according to the method based on the coefficient of abundance-dominance of BraunBlanquet and Massens which established indices varying from + to 5 . This scale has six indices give the distribution of individuals of a species as follows: 
$+=$ simple presence, with average overlap $=0.5$;

$1=$ recovery from 1 to $5 \%$, with average recovery $=3$;

$2=$ recovery from 5 to $25 \%$, with average recovery $=15$

$3=50 \%$ conductivity overlap, with average overlap $=37.5$;

$4=50$ to $75 \%$ overlap, with average overlap $=62.5$;

$5=$ recovery greater than $75 \%$, with average recovery $=87.5$.

These abundance-dominance indices made it possible to calculate the average recovery for each species $(\mathrm{Pi}=\mathrm{RMi} /$ $\sum \mathrm{RM}$ ) with RMi or RM: percentage occupied by this species in a given environment, $\sum \mathrm{RM}$ : Total number of records and the presence index (Pi) corresponds to the average recovery of species i over the total recovery of individuals. The Shannon and Weaver $\left(\mathrm{H}^{\prime}\right)$ diversity index made it possible to appreciate the numerical importance of the taxa of a stand. It was calculated according to the formula:

$\mathrm{H}^{\prime}=-\sum_{\mathrm{i}=1}^{8} \mathrm{Pi} \log _{2} \mathrm{Pi}$

with $\mathrm{Pi}=$ relative abundance of taxon $\mathrm{i}$ and $\mathrm{S}=$ total number of taxa in the sample.

The Pielou (J) Fairness Index. Its formula is: $E^{\prime}=H^{\prime} / \log 2 \mathrm{~S}$ with: $\mathrm{S}=$ total number of taxa in the sample. $\mathrm{E}$ is 0 when only one taxon dominates and 1 when all taxa have the same abundance. The dominance index "d" of Berger and Parker which has the formula $\mathrm{d}=\mathrm{Nmax} / \mathrm{N}$ where Nmax is the maximum abundance or the most frequent number of individuals in the environment and $N$ the total abundance. Sorensen's similarity coefficient (IS), $Q=[2 a /(2 a+b+c)]$ with $0<Q<1$ with $\mathrm{a}=$ number of species common to both environments; $\mathrm{b}=$ number of species present in station $\mathrm{A}$ and absent in station B; c = number of species present in medium B and absent in station A will be used. The Frequency of occurrence has been determined as follows: $\mathrm{F}=(\mathrm{Fi} / \mathrm{Ft}) \times 100$ with $\mathrm{Fi}=$ number of records containing species $\mathrm{i}$; $\mathrm{Ft}=$ total number of readings taken. In the case of phytoplankton, the Frequency of occurrence $(\mathrm{F})$ with $\mathrm{F}=(\mathrm{Pa} / \mathrm{P}) \times 100$ with $\mathrm{Pa}=$ total number of samples containing the species taken into consideration; $\mathrm{P}$ is the total number of samples taken. According to [15], a distinction is made between constant species ( $\mathrm{F} \geq 50 \%)$, accessory species $(25 \%<\mathrm{F}<50 \%)$ and accidental species $(\mathrm{F} \leq 25 \%)$. The phytoplankton density was calculated using the formula: $\mathrm{D}=(\mathrm{n} \times \mathrm{v}) / \mathrm{V}$ where $\mathrm{D}$ is the density (expressed in individuals per liter); $\mathrm{v}$ is the total volume of the sample analyzed and $\mathrm{V}$ is the volume of filtered water in the field.

\subsubsection{Statistical data analysis}

Statistical processing of information on primary producers and the physical/chemical environment was expressed in enumerated numbers and relative abundances. PAST3 software was used to calculate the available indices. Data normality was sought using the Kolmogorov-Smirnov test. The XLSTAT 2007 software was used to perform the nonparametric tests of Kruskal-Wallis and the Mann Withney test. It has also been used to perform Principal Component Analysis (PCA). All the probabilities calculated within the framework of this study were assessed at the $5 \%$ threshold.

\section{Results}

\subsection{Physico-chemical environment of the Kondi and Tongo Bassa rivers}

The results obtained from the $\mathrm{pH}$ measurement in the streams studied reveals a longitudinal variability gradient. Overall, the waters tend to have alkaline character in all six stations with the exception of stations $\mathrm{K} 1$ ( $6.59 \pm 0.75 \mathrm{CU})$ and $\mathrm{T} 1(6.81 \pm 0.10 \mathrm{CU})$ which have $\mathrm{pH}$ acids. The largest mean values of pH were observed in $\mathrm{K} 3(8.92 \pm 0.18 \mathrm{CU})$ and in $\mathrm{T} 3(9.02 \pm 0.40 \mathrm{CU})$ for the Kondi and Tongo Bassa river respectively. The observed saturation rate fluctuates between $7.07 \pm 0.16 \mathrm{mg} / \mathrm{l}(\mathrm{K} 1)$ and $5.07 \pm 0.22 \mathrm{mg} / \mathrm{l}(\mathrm{K} 3)$, in the Kondi river and between $6.27 \pm 0.45 \mathrm{mg} / \mathrm{l}$ (T1) and $4.61 \pm$ $0.40 \mathrm{mg} / \mathrm{l}$ (T3), in river Tongo Bassa. Regarding total dissolved solids (TDS), the recorded values show a similar trend as that of conductivity with the exception of $\mathrm{K} 3$ where the average drops was $0.25 \pm 0.5 \mathrm{mg} / \mathrm{l}$. The highest mean TDS values were obtained in $\mathrm{K} 2(0.31 \pm 0.05 \mathrm{mg} / \mathrm{l})$, in the Kondi and T3 (0.45 $\pm 0.06 \mathrm{mg} / \mathrm{l})$ in the Tongo Bassa. The lowest TDS averages were obtained upstream of the two rivers, including K1 $(0.13 \pm 0.05 \mathrm{mg} / \mathrm{l})$ and T1 $(0.32 \pm 0.05 \mathrm{mg} / \mathrm{l})$. The orthophosphates show that the stations K2 $(2.55 \pm 0.39 \mathrm{mg} / \mathrm{l})$ and T2 $(2.72 \pm 0.42 \mathrm{mg} / \mathrm{l})$ were those with the highest average values. The lowest values being obtained in $\mathrm{K} 1(1.20 \pm 0.10 \mathrm{mg} / \mathrm{l})$ and $\mathrm{K} 3(1.29 \pm 0.09 \mathrm{mg} / \mathrm{l})$ and in T1 (1.41 \pm $0.12 \mathrm{mg} / \mathrm{l})$. The values for ammonia contents obtained in all the stations reveal high contents in $\mathrm{K} 3(68.22 \pm 3.27 \mathrm{mg} / \mathrm{l})$ and T3 (71.52 $\pm 7.58 \mathrm{mg} / \mathrm{l})$, whereas the lowest levels were obtained in K1 (52.68 $\pm 3.83 \mathrm{mg} / \mathrm{l})$ and T1 (56.25 \pm $5.50 \mathrm{mg} / \mathrm{l})$. In the Tongo Bassa river, the chlorine contents, generally located around $10 \mathrm{mg} / \mathrm{l}$, reached maximum values of $10.7 \pm 0.28 \mathrm{mg} / \mathrm{l}$ (T2) and $13.72 \mathrm{mg} / \mathrm{l}$ (T3). The lowest levels in river Kondi are obtained in K1 (7.35 $\pm 0.64 \mathrm{mg} / \mathrm{l})$ and 
K2 $(8.1 \pm 0.63 \mathrm{mg} / \mathrm{l})$. The iron contents vary according to the stations. It was observed from this results that for the Kondi, K2 (4.87 $\pm 0.87 \mathrm{mg} / \mathrm{l})$ and K3 (4.35 $\pm 1.62 \mathrm{mg} / \mathrm{l})$ were those having the highest value, on the contrary of T1 (2.19 $\pm 0.95 \mathrm{mg} / \mathrm{l})$ and T3 $(3.32 \pm 1.39 \mathrm{mg} / \mathrm{l})$, presenting the lowest contents. The nitrates contents vary between $0.27 \mathrm{mg} / \mathrm{l}$ (K1) and $0.73 \mathrm{mg} / \mathrm{l}(\mathrm{K} 2)$ in the Kondi and between $0.3 \mathrm{mg} / \mathrm{l}$ and $0.65 \mathrm{mg} / \mathrm{l}$ reguarding the Tongo Bassa. BOD values are mostly greater than $10 \mathrm{mg} / \mathrm{l}$ with the exception of $\mathrm{K} 1(9.35 \pm 0.95 \mathrm{mg} / \mathrm{l})$, which has the lowest value. The largest values were obtained in $\mathrm{K} 2(13.22 \pm 1.02 \mathrm{mg} / \mathrm{l})$ and T3 (13.4 $\pm 1.62 \mathrm{mg} / \mathrm{l})$. In view of the results, it appears that, for both the Kondi and the Tongo Bassa, the evolution of BOD 5 follows that of TDS. Again, in both the Kondi and the Tongo Bassa rivers, the overall waters were slightly alkaline with values mainly between 7.9 and 9. The recorded values of conductivity reveal that a part from station K1, which has values of conductivity between 0 and $250 \mu \mathrm{S} / \mathrm{cm}$ characteristic of a non-saline environment, Kondi waters tend to be slightly saline (conductivity values between 250 and $500 \mu \mathrm{S} / \mathrm{cm}$ ). On the contrary, the water of the Tongo Bassa generally belong to the category of non-saline water with the exception of T3 $(251.10 \pm 6.90 \mu \mathrm{S} / \mathrm{cm})$ which has slightly saline properties (Table 1$)$.

Table 1 Main chemical characteristics measured in the rivers studied (mean \pm standard deviation).

\begin{tabular}{|c|c|c|c|c|c|c|}
\hline & K1 & K2 & K3 & T1 & T2 & T3 \\
\hline Parameters & Moy \pm Et & Moy \pm Et & Moy \pm Et & Moy \pm Et & Moy \pm Et & Moy \pm Et \\
\hline $\mathrm{pH}(\mathrm{UC})$ & $6,59 \pm 0,75$ & $8,49 \pm 0,29$ & $8,92 \pm 0,18$ & $6,81 \pm 0,10$ & $8,39 \pm 0,12$ & $9,02 \pm 0,40$ \\
\hline DO (mg/l) & $7,07 \pm 0,16$ & $5,24 \pm 0,50$ & $5,07 \pm 0,22$ & $6,27 \pm 0,45$ & $4,79 \pm 0,75$ & $4,61 \pm 0,40$ \\
\hline TDS (mg/l) & $0,13 \pm 0,05$ & $0,312 \pm 0,05$ & $0,25 \pm 0,5$ & $0,32 \pm 0,05$ & $0,375 \pm 0,05$ & $0,45 \pm 0,06$ \\
\hline ORTH (mg/l) & $1,20 \pm 0,10$ & $2,55 \pm 0,39$ & $1,29 \pm 0,09$ & $1,41 \pm 0,12$ & $2,723 \pm 0,42$ & $2,56 \pm 0,17$ \\
\hline AMM (mg/l) & $52,68 \pm 3,83$ & $63,4 \pm 6,29$ & $68,22 \pm 3,27$ & $56,25 \pm 5,50$ & $62,82 \pm 5,08$ & $71,52 \pm 7,58$ \\
\hline $\mathrm{CL}(\mathrm{mg} / \mathrm{l})$ & $7,35 \pm 0,64$ & $8,1 \pm 0,63$ & $9,31 \pm 0,59$ & $9,88 \pm 0,97$ & $10,7 \pm 0,28$ & $13,72 \pm 0,74$ \\
\hline Iron (mg/l) & $2,19 \pm 0,95$ & $4,16 \pm 1,02$ & $3,32 \pm 1,39$ & $4,19 \pm 0,75$ & $4,87 \pm 0,87$ & $4,35 \pm 1,62$ \\
\hline NITR (mg/l) & $0,27 \pm 0,10$ & $0,73 \pm 0,16$ & $0,64 \pm 0,17$ & $0,3 \pm 0,12$ & $0,54 \pm 0,19$ & $0,65 \pm 0,23$ \\
\hline $\mathrm{BOD}_{5}\left(\mathrm{mgO}_{2} / \mathrm{l}\right)$ & $9,35 \pm 0,95$ & $13,22 \pm 1,02$ & $11,63 \pm 1,39$ & $10,71 \pm 0,75$ & $12,85 \pm 0,87$ & $13,4 \pm 1,62$ \\
\hline
\end{tabular}

Avg: average; and: standard deviation; DO: dissolved oxygen; TDS: total dissolved solids; ORTH: orthophosphates, AMM: Ammonia, CL: chlorine, NITR: nitrate, BOD 5 : biological oxygen demand

\subsubsection{Typology of stations}

Synthesis of physical and chemical data from the Pearson correlation in the rivers studied, highlights a strong matrix of positive correlations between depth and turbidity, water depth and $\mathrm{pH}$, water depth and conductivity, depth of water and nitrates, temperature and turbidity, temperature and $\mathrm{pH}$, turbidity and $\mathrm{pH}$, turbidity and conductivity, dissolved oxygen and transparency, turbidity and ammonia, $\mathrm{pH}$ and conductivity, $\mathrm{pH}$ and ammonia, ammonia and water temperature, $\mathrm{pH}$ and nitrates, conductivity and nitrates, TDS and chlorine, TDS and iron, TDS and BOD5, orthophosphates and $\mathrm{BOD}_{5}$, current velocity and dissolved oxygen and between nitrates and BOD5. Strong negative correlations also exist between turbidity and dissolved oxygen, $\mathrm{pH}$ and dissolved oxygen, transparency and TDS, between transparency and chlorine, current speed and water temperature, speed current and turbidity, current speed and $\mathrm{pH}$, current speed and ammonia, dissolved oxygen and nitrates and between dissolved oxygen and BOD 5 (Table 2). The values of the physical and chemical parameters presented significant differences between them $(p=0.000, \alpha=$ 0.05). 
Table 2 Correlation matrix (Pearson) of the physical and chemical parameters of the Kondi and Tongo Bassa rivers.

\begin{tabular}{|c|c|c|c|c|c|c|c|c|c|c|c|c|c|c|c|}
\hline Variables & WD & $\mathbf{W T}^{\circ}$ & TURB & TRANS & pH & COND & DO & TDS & ORTH & AMM & CL & Iron & NITR & BOD5 & SP \\
\hline WD & 1 & & & & & & & & & & & & & & \\
\hline $\mathrm{WT}^{\circ}$ & 0.521 & 1 & & & & & & & & & & & & & \\
\hline TURB & 0.849 & 0.872 & 1 & & & & & & & & & & & & \\
\hline TRANS & -0.315 & -0.761 & -0.625 & 1 & & & & & & & & & & & \\
\hline $\mathrm{pH}$ & 0.873 & 0.839 & 0.987 & -0.665 & 1 & & & & & & & & & & \\
\hline COND & 0.921 & 0.638 & 0.904 & -0.299 & 0.866 & 1 & & & & & & & & & \\
\hline DO & -0.741 & -0.810 & -0.921 & 0.822 & -0.946 & -0.740 & 1 & & & & & & & & \\
\hline TDS & 0.380 & 0.576 & 0.553 & -0.947 & 0.617 & 0.301 & -0.803 & 1 & & & & & & & \\
\hline ORTH & 0.496 & 0.295 & 0.479 & -0.666 & 0.598 & 0.276 & -0.736 & 0.778 & 1 & & & & & & \\
\hline AMM & 0.791 & 0.913 & 0.956 & -0.761 & 0.963 & 0.796 & -0.918 & 0.688 & 0.516 & 1 & & & & & \\
\hline CL & 0.171 & 0.737 & 0.498 & -0.964 & 0.534 & 0.149 & -0.673 & 0.878 & 0.513 & 0.689 & 1 & & & & \\
\hline Iron & 0.320 & 0.351 & 0.448 & -0.776 & 0.497 & 0.294 & -0.738 & 0.897 & 0.780 & 0.483 & 0.624 & 1 & & & \\
\hline NITR & 0.789 & 0.850 & 0.961 & -0.715 & 0.983 & 0.779 & -0.960 & 0.644 & 0.661 & 0.935 & 0.580 & 0.531 & 1 & & \\
\hline BOD5 & 0.771 & 0.576 & 0.784 & -0.756 & 0.857 & 0.645 & -0.930 & 0.842 & 0.890 & 0.809 & 0.597 & 0.799 & 0.858 & 1 & \\
\hline SP & -0.572 & -0.949 & -0.858 & 0.800 & -0.824 & -0.683 & 0.821 & -0.686 & -0.299 & -0.930 & -0.776 & -0.475 & -0.794 & -0.637 & 1 \\
\hline
\end{tabular}

The values in bold are significantly different from 0 at a significance level alpha $=0.05 . \mathrm{DO}=$ Dissolved Oxygen, $\mathrm{ORTH}=0 \mathrm{Orthophosphates,} \mathrm{WT}{ }^{\circ}=$ Water temperature, $\mathrm{TDS}=$ Total Solids Dissolved, $\mathrm{pH}=$ hydrogen potential, $\mathrm{COND}=$ Conductivity, TURB $=$ Turbidity, $\mathrm{WD}=\mathrm{Water}$ depth, $\mathrm{TRANS}=$ transparency, $\mathrm{BOD}_{5}=$ Biological Oxygen Demand obtained in 5 days, $\mathrm{AMM} .=$ Ammonia, CL: Chlorine, NITR. $=$ Nitrates, SP $=$ speed of the stream

\section{2. - Synthesis of physicochemical data from the Principal Component Analysis}

Considering all the stations of the rivers studied, the examination of the PCA on the F1 (99.23\% inertia) x F2 (0.64\% inertia) plans, represented in the form of circle of correlations shows that the factorial axis F2 opposes two sets of variables. It is negatively correlated with the elements of the first set containing descriptors very well correlated with each other which are the stations K2, K3, T2 and T3. This factorial axis is positively correlated with stations K1 and T1 located upstream from the rivers studied (Fig. 2). However, these stations do not show significant differences between them $(p=0.976 ; \alpha=0.05)$.

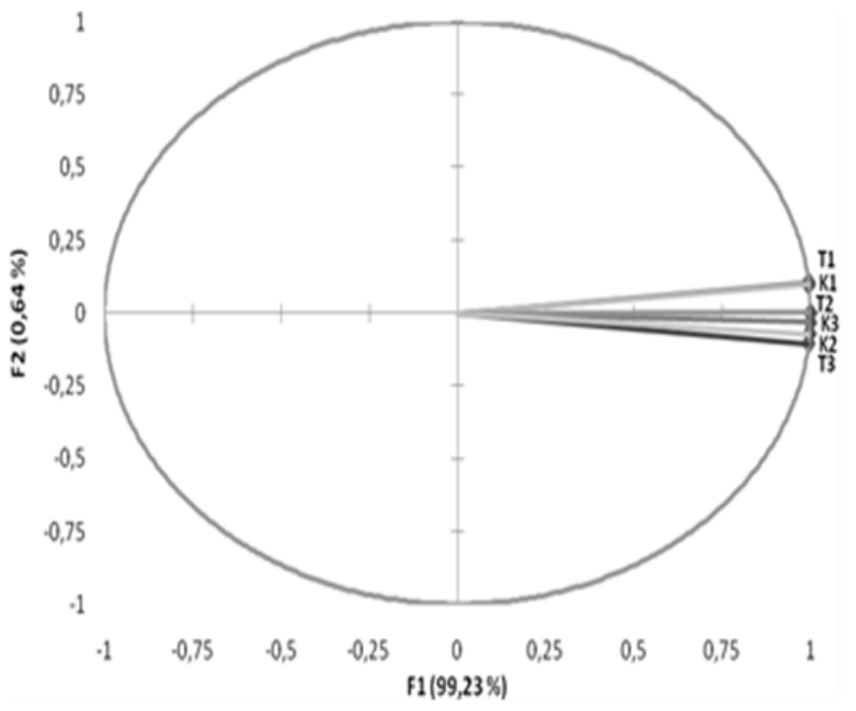

Figure 2 Projection of the study stations described by their physicochemical characteristics, on the plane of the first two factorial axes of the Kondi and Tongo Bassa. K1: station K1, K2: station K2, K3: station K3, T1: station T1, T2: station T2, T3: station T3 
Taking the two rivers studied, the correlations established between the 15 physical and chemical variables on the F1 (72.81\% inertia) x F2 (14.82\% inertia) plans of the PCA brings out two plans according to F1. The factorial axis F1 is positively correlated with transparency, current speed and dissolved oxygen. It is negatively correlated with iron, total dissolved solids, orthophosphates, chlorine, $\mathrm{BOD}_{5}$, ammonia, water temperature, water depth, turbidity, $\mathrm{pH}$, nitrates and conductivity. The observations made along the factorial axis F2 show a positive correlation between this axis and the dissolved oxygen, the transparency, the conductivity, the water depth, the $\mathrm{pH}$, the turbidity, the nitrates, the ammonia and the water temperature. This axis is negatively correlated with six parameters including the speed of the current, total dissolved solids, $\mathrm{BOD}_{5}$, orthophosphates, chlorine and iron, strongly correlated (Fig.3). Significant differences exist between the physical and chemical parameters of the six stations of the rivers studied $(p=0.0001 ; \alpha=$ 0.05).

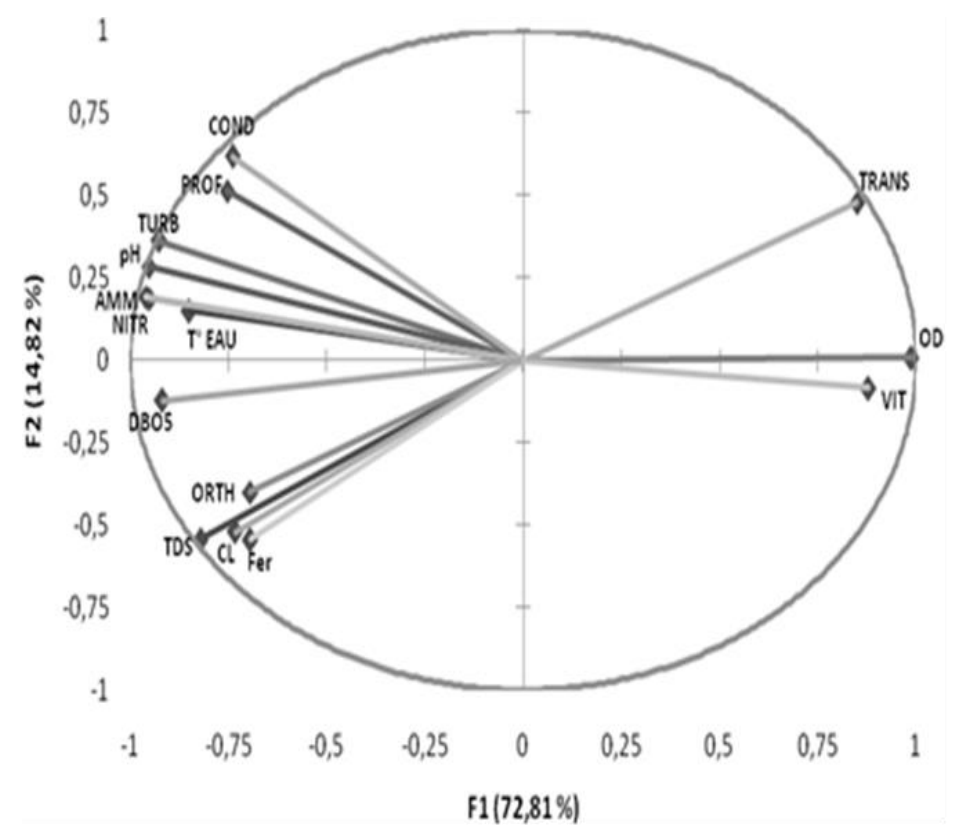

Figure 3 Analysis in Principal Components of the physico-chemical parameters measured at the level of the various stations of study of the rivers Kondi and Tongo Bassa, DO = Dissolved Oxygen, ORTH $=$ Orthophosphates, $\mathrm{WT}^{\circ}=\mathrm{Water}$ temperature, TDS = Total Solids Dissolved, $\mathrm{pH}=$ hydrogen potential, COND = Conductivity, TURB = Turbidity, WD = Water depth, TRANS = transparency, BOD5 = Biological Oxygen Demand obtained in 5 days, AMM. = Ammonia, CL: Chlorine, NITR. $=$ Nitrates, $\mathrm{SP}=$ speed of the stream.

\subsection{Specific richness and structure of the macrophyte communities of the rivers studied}

The general physiognomy of the flora of this wetland shows that the upstream is less diversified than the downstream with 89 listed species. The station K3 is the most diversified (73 species) followed by K2 (54) and K1 (50). In general, the frequency of occurrence reveals that the majority of species are accidental species ( $\mathrm{F}<25 \%)$. However, it appears upstream that two species are incidental $(25 \% \leq \mathrm{F}<50 \%)$. These are Ipomoea involucrata and Cyathula prostrata. Commelina benghalensis and Setaria barbata are constant ( $\mathrm{F} \geq 50 \%)$. In transition, Pennisetum purpureum is the only accessory species while Commelina benghalensis is the only constant species. Downstream, we note that all the species found there were accidentally present, with the exception of Alternanthera sessilis, Eleusine indica which were incidental. The constant species were Nymphaea lotus, Acroceras amplectens, Pennisetum purpureum and Setaria barbata. This inventory also made it possible to assessed 89 species belonging to 29 families. We founded Acanthaceae (04), Amaranthaceae (04), Araceae (05), Asteraceae (10), Capparaceae (01), Cleomaceae (01), Commelinaceae (02), Convolvulaceae (04), Cucurbitaceae (02), Cyperaceae (09), Dennstaedtiaceae (01), Euphorbiaceae (03), Fabaceae (03), Lamiaceae (01), Melastomataceae (01), Mimosaceae (02), Musaceae (01 species), Nymphaeaceae (01), Onagraceae (04), Oxalidaceae (01 species), Phyllanthaceae (01), Piperaceae (01), Plantaginaceae (01), Poaceae (18), Polygonaceae (01), Portulacaceae (01), Rubiaceae (03), Solanaceae (03), and Urticaceae (01). Regarding the structure of macrophytes, the most diverse family is that of Poaceae, followed by that of Asteraceae and Cyperaceae. The least represented families with 01 species each were Capparaceae, Cleomaceae, Dennstaedtiaceae, Lamiaceae, Melastomataceae, Musaceae, Nymphaeaceae, Oxalidaceae, Phyllanthaceae, Piperaceae, Plantaginaceae, Polygonaceae, Urticaceae. In addition, the proportions of representativeness showed that the Poaceae family was the most represented with $64.28 \%$ while the least represented families were those comprising 01 species corresponding to $3.57 \%$. 
Overall, 58 species were found on the Tongo Bassa. Maximum richness ( 45 species) was observed at station T1 followed by T2 (42), while the lowest richness is observed at station T3 (32). The general physiognomy of the vegetation in this watercourse shows that the upstream and the transition were more diversified than the downstream. Analysis of the percentages of occurrence generally indicates that the majority of species are accidental (F <25\%). However, 05 accessory species are observed upstream (25\% $\leq \mathrm{F}<50 \%)$. These were Amaranthus esculentus, Amaranthus spinosus, Chromolaena odorata, Synedrella nodiflora and Eleusine indica. The species Alternanthera sessilis, Commelina benghalensis, Setaria barbata and Pennisetum purpureum are constant (F $\geq 50 \%$ ). In transition, only 02 species were incidental. These are Amaranthus spinosus and Eleusine indica while 03 species are constant there (Alternanthera sessilis, Commelina benghalensis and Pennisetum purpureum). Downstream, Commelina benghalensis was incidental while the group of constant species consists of Alternanthera sessilis, Amaranthus spinosus and Pennisetum purpureum. This wealth presents 20 families comprising 58 species. We found Acanthaceae (02), Amaranthaceae (04), Araceae (04), Asteraceae (06), Capparaceae (01), Commelinaceae (01), Convolvulaceae (03), Cucurbitaceae (01), Cyperaceae (07), Dennstaedtiaceae (01), Fabaceae (02), Lamiaceae (01), Musaceae (01), Onagraceae (04), Phyllanthaceae (01), Piperaceae (01), Plantaginaceae (01), Poaceae (14), Polygonaceae (01 species), Portulacaceae (01), and Rubiaceae (01). As with Kondi, the structure of macrophytes brought out the predominance of the Poaceae family, which was the most diversified, followed by Cyperaceae and Asteraceae. The least represented families with 01 species each were Capparaceae, Commelinaceae, Cucurbitaceae, Dennstaedtiaceae, Lamiaceae, Musaceae, Melastomataceae, Musaceae, Nymphaeaceae, Oxalidaceae, Phyllanthaceae, Piperaceae, Planteraceae Polygonaceae, Portulacaceae, and Rubiaceae. The representation proportions showed that the Poaceae family is the most represented with $66.66 \%$ while the least represented families were those comprising 01 species corresponding to $4.76 \%$.

\subsection{Diversity of macrophytic communities}

\subsubsection{ShannonWeaver Clues and Piélou Diversity}

For the Kondi, the diversity index of Shannon and Weaver was greater than 3. The station K3 (3.58) has the highest index value, while the lowest value was obtained in K2 (3.17). In the Tongo Bassa, this index fluctuates between 1.87 and 2.42 with the highest value obtained in T3 and the lowest in T2 (Fig. 4). Regarding Piélou's Fairness, the values varied in the Kondi from 0.82 (K2) to 0.88 (K3). The Tongo Bassa, on the other hand, had a fairness range between 0.49 (T2) and 0.7 (T3) (Fig. 4).

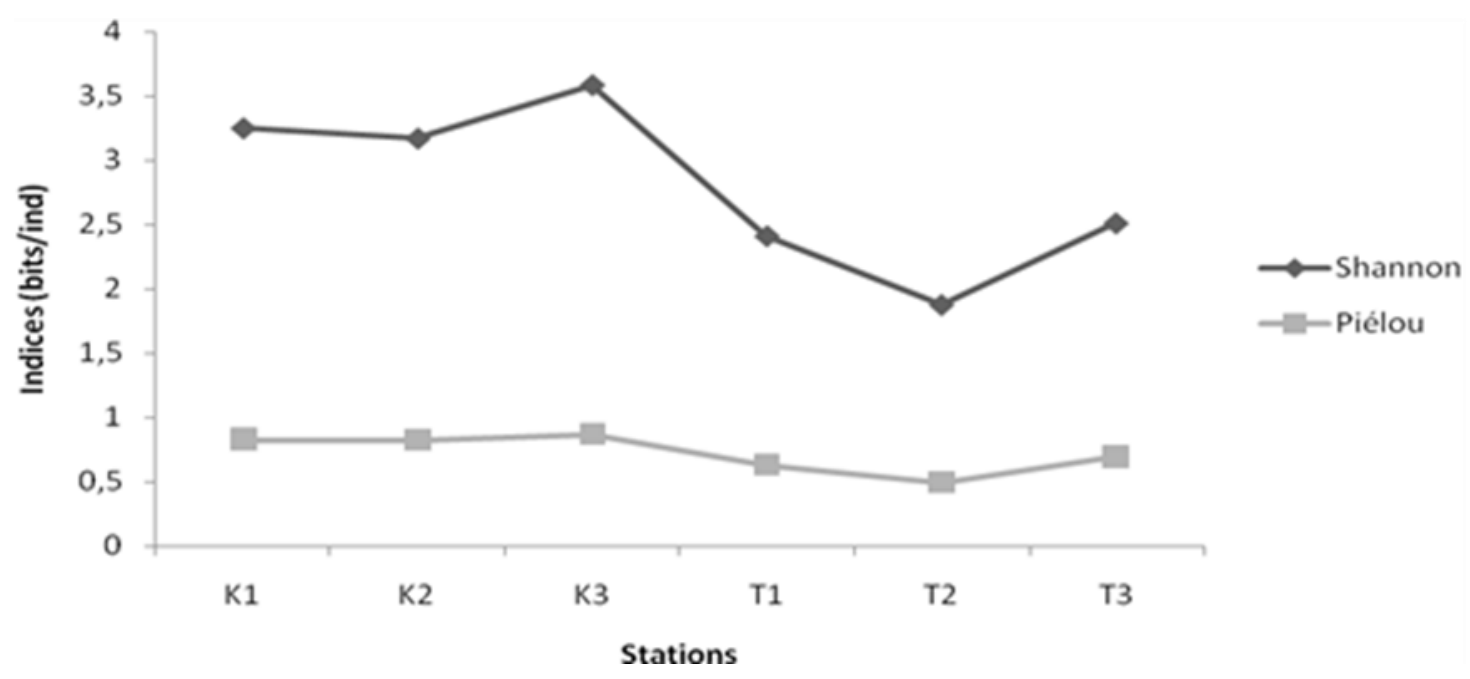

Figure 4 Variations in the Shannon and Piélou indices of the macrophyte communities: Kondi (K1: station 1, K2: station 2; K3: station 3) and Tongo Bassa (T1: station 1, T2: station 2; T3: station 3)

\subsubsection{Berger-Parker index}

Looking at the river Kondi, the Berger-Parker Dominance index for the stations studied showed a decreasing trend from 0.15 bits / ind (K1 and K2) to 0.07 bits / ind (K3). In the Tongo Bassa river, this index oscillated between 0.27 bits / ind (T1) and 0.38 bits / ind (T2) with 0.28 bits / ind in T3 (Fig. 5). The values of these indices indicated high diversity with low domination. 


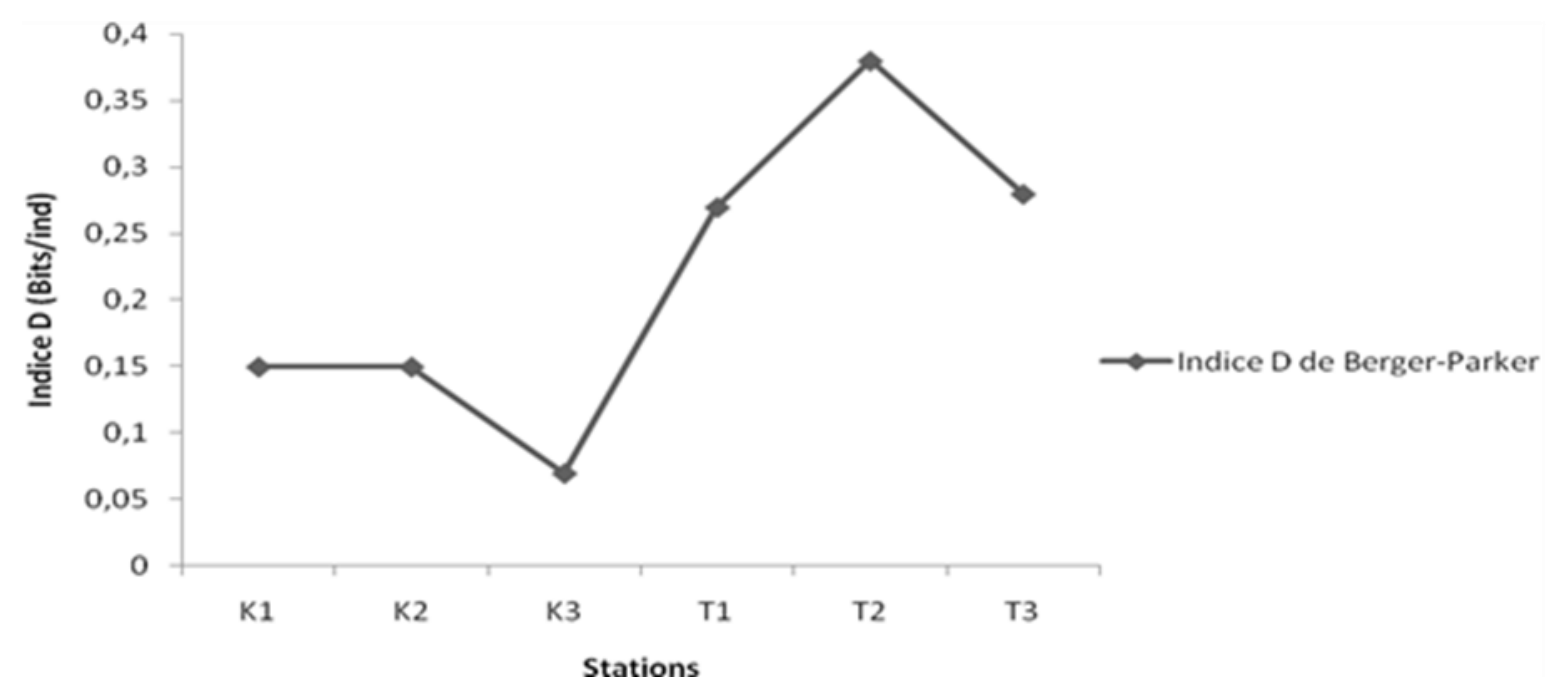

Figure 5 Variations of the Berger-Parker index of macrophyte communities: Kondi (K1: station 1, K2: station 2; K3: station 3) and Tongo Bassa (T1: station 1, T2: station 2; T3: station 3)

\subsubsection{Similarity of Sörensen}

Sörensen's similarity index were greater than 0.5 overall. We observed relatively high similarities in the specific composition of macrophyte communities when analysing the various points two by two. The same was true for rivers taken two by two (Table 3). In addition, the evolution of the similarity index over all of the rivers studied shows that there is no significant difference between the stations $(\mathrm{p}=1 ; \alpha=0.05)$.

Table 3 Sörensen's Similarity Coefficient of Phytoplankton in the rivers studied.

\begin{tabular}{|l|l|}
\hline Stations & Indices de Smilitude \\
\hline Kondi & 0,65 \\
\hline K1-K2 & 0,61 \\
\hline K1-K3 & 0,71 \\
\hline K2-K3 & 0,72 \\
\hline Tongo Bassa & 0,51 \\
\hline T1-T2 & 0,65 \\
\hline T1-T3 & 0,67 \\
\hline T2-T3 & \\
\hline Kondi-Tongo Bassa &
\end{tabular}

\subsubsection{Main Component Analysis of Macrophyte Communities}

Concerning the projection of the stations, the first two axes F1 and F2 of the AFC cumulate 94.13\% of the information explained and discriminated the stations into two groups characterized by assemblies of different macrophytes (Fig.6). These two clearly differentiated groups highlight three characteristic macrophyte structures. Group 1 corresponds to stations T1, T2 and T3 characterized by a predominence of Setaria barbata, Alternanthera sessilis and Amaranthus spinosus. Group 2 brings together the K1 and K2 stations which have a macrophytic stand dominated by Pennisetum purpureum, Commelina benghalensis and Astasia gangetica. Group 3, for its part, includes the station K3, Nymphaea lotus and Acroceras amplectens (Fig. 6). There is a significant difference between the stations based on the abundance of constant species $(\mathrm{p}<0.0001, \alpha=0.05)$. 


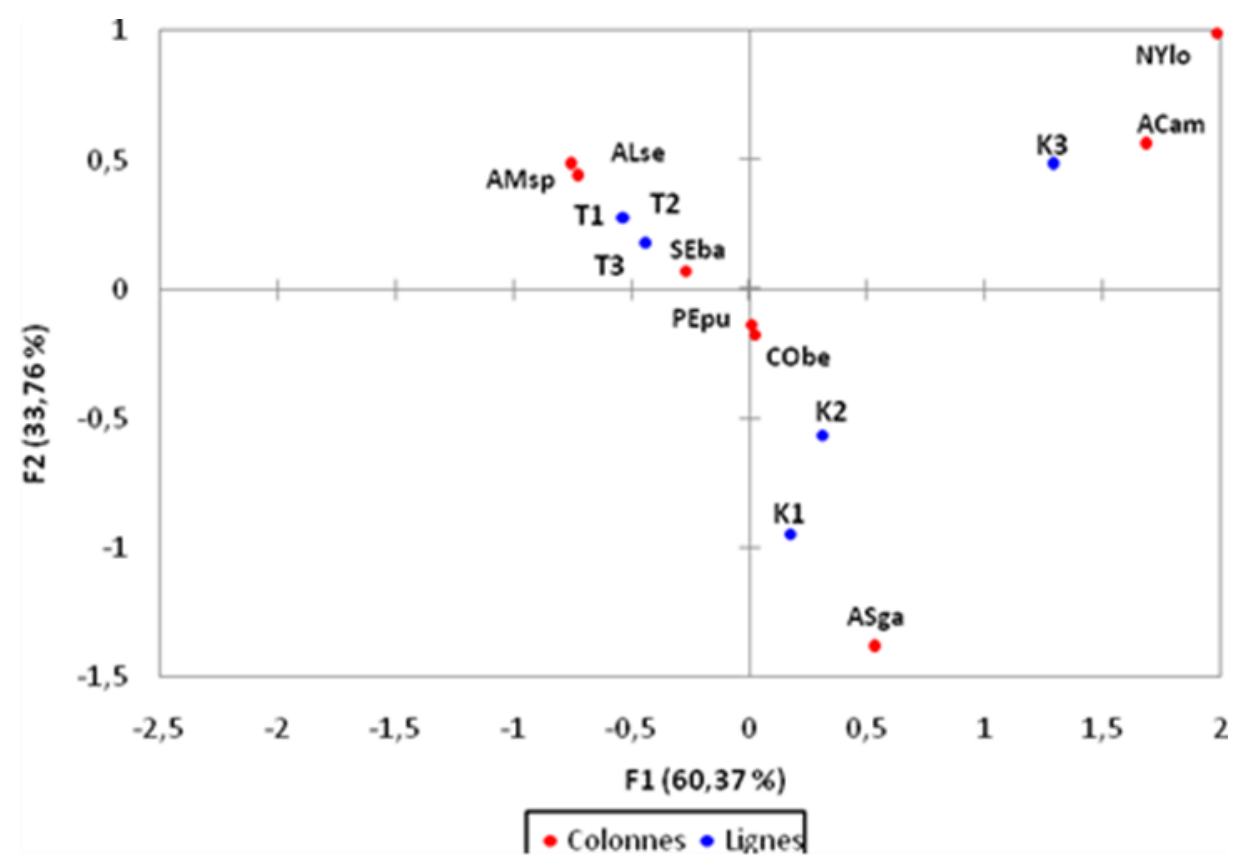

Figure 6 Projections of the stations, described by their macrophyte communities, on the plan of the first two factorial axes of the AFC on the rivers studied: ACam : Acroceras amplectens, Cobe : Commelina benghalensis, PEpu : Pennisetum purpureum, NYlo : Nymphaea lotus, ALse : Alternanthera sessilis, SEba : Setaria barbata, AMsp: Amaranthus spinosus, ASGA : Asystasia gangetica, AMsp : Amaranthus spinosus

\section{Discussion}

Coastal rivers, through their mouths are subject to the influence of the tide. During high tide, the saline waters propagate in the rivers inland in the form of a wave, thus varying the level of the river, its direction of flow as well as its chemistry. It is known that temperature is a key physical parameter that plays an essential role in biological phenomena within water bodies [5]. In general, the surface water temperature is a parameter strongly influenced by climatic conditions. Although in a coastal region regularly watered during the rainy season, the surface waters of the rivers studied remain at a warm temperature with considerable variations. This situation would be due to a sampling spread over two seasons, the sunshine linked to urbanization and the multiple water supplies coming from the effluents of the watershed as well as factors external to hydrosysytemes which are, among other things, exposure. [13] reveals that the inflows of water by the tributaries, having a higher temperature than those of the waters of a lake, and the frequent winds can also constitute a factor of disturbance of the thermal stratification of the water column. The temperature of watercourses varies with the weather and, depending on the month, depending on the weather. The temperature of surface waters is directly influenced by climatic conditions. In addition, some species prefer warmer waters [15]. However, the thermal state of the waters of Kondi and Tongo Bassa is comparable to that found in the Kambo river in Douala by [16]. According to [17], in a watercourse, transparency varies depending on the abundance of suspended particles (clay, silt, etc.). This statement is consistent with the results obtained on the two rivers as a whole, because the relatively lowest values are obtained downstream, an area with a high representation of macrophytes on the Kondi. [13] points out that the low values of transparency can be attributed to the action of the winds. The latter cause turbulence which resuspends the particles of sediment. In addition to this, there are non-native sedimentary inflows conveyed by tributaries from watershed. Also, the clear water phase (transparency) is linked to the development of zooplankton communities which significantly contribute to the variation of transparency through the browsing of phytoplankton ([18]; [19]). The high turbidities recorded could be explained by a significant contribution of solid particles from the leaching of the soils of the watershed during flood [20]. Referring to the Berg speed scale, the waters of the rivers studied belong globally to the so-called fast current category due to the high speeds recorded during the rainy season. With the exception of stations $\mathrm{K} 1$ and $\mathrm{T} 1$ to a certain extent, where the electrical conductivities indicate moderate mineralization, the water conductivity values of the other stations show strong mineralization which could be explained by the fact that these stations received domestic and urban effluents because of their location in very densely populated areas or near industrial zones. An identical observation was made by [12] who also noted very high values of electrical water conductivities in the Kondi river. The Average $\mathrm{pH}$ values showed that, the waters are generally basic with the exception of $\mathrm{K} 1$ and $\mathrm{T} 1$. The acidity of the waters at station $\mathrm{K} 1$ and $\mathrm{T} 1$ can be justified by the acidic nature of the soil in Douala and by the upstream situation of this station. According to [21], the pH generally varies in natural waters between 5 and 9 
This slight increase can be explained by the increase in biological activity from upstream to downstream of rivers as indicated by [22] associated with the contribution of effluents from surrounding industries and markets. Indeed, the processes of mineralization of organic matter would release $\mathrm{CO}_{2}$ entering the formation of hydrogen carbonates which increase the pH values of water. [10] during studies in Kondi also reached similar conclusions. Analysis of the longitudinal profiles of the dissolved oxygen content in the rivers studied shows that, overall, the dissolved oxygen varies decreasing from upstream to downstream. In contrast, the low oxygenations recorded in the study stations are due to their high organic matter loads due to the intensification of precipitation during the rainy season. In addition, this regression in mean values from upstream to downstream can suggest a gradual increase in the amount of organic matter discharged into the ecosystem. On this subject, [23] point out that precipitation and runoff are charged with oxygen and thus constitute an important oxygen supply for watercourses. Overall, the content of TDS increases from upstream to downstream in relation to the discharge of leaching water from dwellings and to agro-pastoral activities carried out around these streams. These activities generate dissolved particles which prevent the water stability necessary for the establishment and development of organisms [24]. The highest TDS content in K2 could mainly result from the upstream discharge of organic effluent from the "Sociéte Anonyme des Brasseries du Cameroun" (SABC), the "Cotonnière Industrielle du Cameroun" (CICAM), the "Compagnie Equatoriale des Peintures" (CEP), Transformation Reef Cameroon (TRC), the Hysacam landfill and the market of PK 8. As for T2 and T3, the same phenomenon can be observed with the activities carried out by SIC CACAO, Guinness and the market by Makèpè Missokè. [10] incriminated the same sources of pollution during his work carried out on the Kondi. Added to this, we can highlight the intense agricultural activity carried out along the Tongo Bassa compared to Kondi. Indeed, Phosphorus is easily drain towards watercourses by effluent discharges, runoff and all residual or agricultural spills, human excrement and detergents used by adjoining people. [25] have shown that discharges of water are generally the main source of water pollution by phosphates and has thus highlighted the role of phosphorus in the eutrophication of watercourses when we know that orthophasphates ions represent the only forms of phosphorus (P) use in agriculture. The high contents of ammonia in waters that progressively change from upstream to downstream would reflect the richness of these waters in decomposing organic matter. These observations are in agreement with the concept of the river continuum that considers downstream sectors of watercourses to be zones of sedimentation dominated by deposits of organic matter [26]. In addition, in general, natural waters contain little total ammonia, the concentrations there usually being less than $0.1 \mathrm{mg} / \mathrm{l}$ [27]. In addition, the average levels of ammonia above $50 \mu \mathrm{g} / \mathrm{l}$ in the various stations highlight water pollution and could suggest sources of pollution upstream of these stations [28]. This pollution could be anthropogenic and / or organic because this element is used in various fields of industry including the manufacture of detergents and cleaning products, the treatment of water reserves, the manufacture of synthetic fibers in industry textiles. Regarding iron, [28] indicate that in surface waters, its concentrations are a few $\mathrm{mg} / \mathrm{l}$, which was the case in all of the sampled stations of the rivers studied. The iron concentration values obtained during this study clearly showed an increase at from K2 for the Kondi, while in the Tongo Bassa, the highest concentration was obtained in T1. These concentrations highlight the impact of Socafer's activities in the waters of Tongo Bassa, to which should be added activities of local residents. In the case of the Kondi, the considerable concentration of iron would come from the activities of the various workshops, the waste of which are associated with those of the local residents, and discharged into the river. In addition, it is also likely that the ferrous ions which pass through the studied streams are introduced there by water or by sediments resulting from erosion. This situation therefore has a double origin, natural and anthropic. Indeed, according to [29], waters also transport dissolved iron and manganese, but their contents vary considerably due to the changing chemical conditions encountered in aqueous medium and because iron and dissolved manganese are easily involved in chemical (adsorption, precipitation, for example), even biological processes. Overall, the nitrate levels are less than $1 \mathrm{mg} / \mathrm{l}$. These results are in the range of those obtained by [30] following the assessment of the water quality of the Kambo and Longmayangui rivers. Even though the contribution remains mainly agricultural, nitrates also affect surface water probably coming from groundwater and the discharge of urban wastewater. Nitrates are also one of the parameters used to qualify the state of water. The $\mathrm{BOD}_{5}$ values are low and very unrepresentative with regard to the results obtained by [10] [31] following the work carried out in the coastal zone of southern Cameroon, where the value of BOD ${ }_{5}$ has reached hundreds of $\mathrm{mg} / \mathrm{l}$. Furthermore, in view of the Moroccan standard on river waters and given the BOD 5 values obtained, the waters of the rivers studied are of poor conditions. For this study, the effects of activities related to the dumping of petroleum residues observed in the rivers studied were not particularly studied. However, many other forms of accidental and non-accidental pollution have contributed to the modification of the characteristics of these bodies of water. The PCR performed from the values of the 15 physical and chemical parameters measured makes it possible to differentiate two major groups of stations (Fig. 33). The group represented by K1 and T1 characterized by their high concentration of dissolved oxygen and relatively low organic matter attributed to the contributions of domestic wastewater. The stations, whose physical and chemical characteristics are generally close, can be assimilated to eutrophic waters and constitute all of the least polluted sites in our study. The group composed of K3, T2, K2 and T3 is characterized by the waters heavily loaded with organic matter. Indeed, in addition to the domestic wastewater incriminated in the first group, these stations receive water rich in organic matter from the SABC (K2), the PK8 and "Cité des Palmiers" markets (K2 and K3), Makèpè Missokè (T3) and Sic Cacao (T2). However, these waters are depleted in 
dissolved oxygen, which seems to be a consequence of the aerobic degradation of the organic substances contained in these discharges [32]. The water of these stations are highly charged with organic matter and can be assimilated to hypereutrophic water. Concerning the macrophytes structure in the rivers studied, the Tongo Bassa appears to be the most diversified river. The values of specific richness and diversity indices are high from upstream to downstream in each water body. [10] came to the same conclusion after working in the Kondi. In fact, the more degraded the environment, the less diversify it is [33]. This affirmation finds it's meaning as the observations made on the Kondi and the Tongo Bassa reveal various anthropic pressures undergone by these rivers in their upstream parts. During the study, the Asteraceae, Acanthaceae, Araceae, Commelinacea, Cucurbitaceae, Cyperaceae, Fabaceae, Solanaceae, Rubiaceae, Poaceae, Piperaceae, Lamiaceae and Melastomataceae were encountered Mimosaceae. Both on the Kondi and on the Tongo Bassa, the Poaceae constitute the most diversified family. Following the work carried out in Kondi, [10] provide an identical conclusion by stating that this family is the most diverse. In general, the majority of species are classified as accidental. [34] has shown that interspecific competition significantly influences the distribution of vegetation, because if a species settles first, its growth and proliferation can inhibit the growth of another arrival secondarily. However, the accidental character of these species could be explained by the fact that regular installation of factories whose activities impact the physical and chemical parameters of these rivers. [35] have shown that when the environment is subject to anthropogenic disturbances such as eutrophication, the specific richness tends to decrease. The higher similarity index between stations $\mathrm{K} 2$ and $\mathrm{K} 3$ and between T1 and T2 indicates that the greatest number of common species was found between transitions and downstream. The results showed that the structure of macrophytes between the upstream and downstream of the rivers studied is due to the variation in the physical and chemical parameters specific to each body of water, or even to each station. [36] also believe that light, temperature, current velocity, phosphorus, nitrogen and inorganic carbon are factors that influence macrophytes growth in small rivers. [37] confirm this result by stating that the growth of macrophytes seems more sensitive to the physical environment downstream, as the depths and current velocities increase, while the nutrients are no longer limiting. [10] claim that macrophytes are not randomly distributed in an environment. They have a longitudinal zonation according to rivers and that physical and chemical factors are not the only parameters responsible for the distribution of the main stractification [38]. We can therefore resume that the quality of water depends natural factors (soil, subsoil, ...) and human activities (agricultural, industrial and domestic) producing discharges which are found directly or indirectly determining aquatic environments.

\section{Conclusion}

The relatively high values of the physical and chemical parameters; Ammonia, orthophosphates and nitrates that particularly influence the distribution of macrophytes on the Kondi and Tongo Bassa rivers. These parameters indicate that the waters included high organic matter loads; which would indicate organic pollution. In addition, the biological elements constitute visible markers of environmental disturbances and were considered as parameters to be taken into account in the assessment of the ecological state of these watercourses. The plant communities encountered in Kondi and Tongo Bassa rivers were relatively rich and diversified and were distributed according to a decreasing gradation of mineralization and trophy. Also, the Piélou index in these rivers is generally below 0.55 reflecting water of poor quality. A study of the structure of macrophyte communities reveals that they are generally dominated by a few species, including the Poaceae Pennisetum purpureum, species characteristic of eutrophic environments. Three groups of macrophytes were observed depending on the characteristics of the rivers studied. However, the distribution of species according to physical and chemical parameters shows that the presence or absence of a species is consecutive to the composition of the environment in nutrients.

\section{Compliance with ethical standards}

\section{Acknowledgments}

We thank the Laboratory of Botany of The University of Douala for having put the material at our disposal.

\section{Disclosure of conflict of interest}

There is no conflict of interest.

\section{References}

[1] Malmqvist B, Rundle S. Threats to the running water ecosystems of the world. Environmental Conservation. 2002; 29. 
[2] Bollache L, Devin S, Wattier R, Chovet M, Beisel JN, Moreteau JC, Rigaud T. Rapid range extension of the PontoCaspian amphipod Dikerogammarus villosus in France: potential consequences. Archiv für Hydrobiologie. 2004; 160: 57-66.

[3] Buchez A, Dorigo U, Rimet F. Surveillance des impacts environnementaux d'effluents aqueux de sites industriels par les diatomées dulçaquicoles. Etude Record n071016/1A. 2006; 175.

[4] Hébert S. Développement d'un indice de qualité bactériologique et physico-chimique de l'eau pour les rivières du Québec. Québec, Ministère de L'Environnement et de la Faune, Direction des écosystèmes aquatiques, Envirodoq $\mathrm{n}^{\circ}$ En/970102, 20p, 4 annexes. 1997.

[5] Cellamare. Évaluation de l'Etat Ecologique des Plans d'Eau Aquitains à partir des Communautés de Producteurs Primaires. Thèse de doctorat PhD. Spécialité : Écologie évolutive, fonctionnelle et des communautés. 2009; 2931.

[6] MINEE (Ministère de l'Eau et de l'Energie). Ministère de l'Energie et de l'Eau, Plan d'action national de gestion intégrée des ressources en eau (PANGIRE). Etat des lieux du secteur Eau et environnement. 2009.

[7] Amis MA, Rouget M, Balmford A, Thuiller W, Kleynhans CJ, Day J, Nel J. Predicting freshwater habitat integrity using land-use surrogates. Water SA. 2007; 33: 215-222.

[8] Foto Menbohan S, Zebaze Togouet SH, Nyamsi Tchatcho NL, Njine T. Evolution spatiale de la diversité des peuplements de macroinvertébrés benthiques dans un cours d'eau anthropisé en milieu tropical (Cameroun). European Journal of Scientific Research. 2011; 55(2): 291-300.

[9] Baok G. Pollution des eaux de rivière et impact sur les populations riveraines. Cas de la rivière Ngoua dans la zone industrielle de Douala Bassa. 2007.

[10] Priso RJ, Oum GO, Din N. Utilisation des macrophytes comme descripteurs de la qualité des eaux du ruisseau Kondi dans la ville de Douala (Cameroun-Afrique Centrale). J. Appl. Biosci. 2012; 53: 3797-3811.

[11] Taffouo VD, Ikoli Saya RA, Oben Mbeng L, Tomedi Eyango M. Impacts des caractéristiques physico-chimiques des eaux sur la distribution du phytoplancton et des macrophytes de la rivière Nkam (Cameroun). Int. J. Biol. Chem. Sci. $2017 ; 11(4):$ 1766-1784.

[12] Onana FM, Zebaze TSH, Nyamsi TNL, Domche THB, Ngassam P. Distribution spatio-temporelle du zooplancton en relation avec les facteurs abiotiques dans un hydrosystème urbain : le ruisseau Kondi, Douala-Cameroun. Journal of Applied Biosciences. 2014; 82: 7326 - 7338.

[13] Groga N. Structure, fonctionnement et dynamique du phytoplancton dans le lac de Taabo (Côte d'Ivoire). Thèse de Doctorat, université de Toulouse. 2012; 27-224.

[14] Durand JM. The irrigables soils. ACCT/PUF, Paris. 1983; 339.

[15] Dajoz R. Précis d'écologie. 5e édition, Bordas, Paris. 1985; 525.

[16] Dibong SD, Ndjouondo GP. Inventaire floristique et écologie des macrophytes aquatiques de la rivière Kambo à Douala (Cameroun). J. Appl. BioSci. 2014; 80: 7147-7160.

[17] Balvay G. Structure, fonctionnement du réseau trophique dans les retenues artificielles. Gestion piscicole des lacs et retenues artificielles. INRA, Paris. 1985; 39-66.

[18] Jabari E. Structure, dynamique des populations zooplanktons de la retenue de barrage Allal El Fassi. Th. 3e cycle Université SMBA. 1988; 197.

[19] Tuzin D, Mason. La clarification des eaux dans les lacs reservoirs. 1996; 56.

[20] Gonzalez EJ, Ortaz M, Penàterrera C, Infante A. Physical and chemical features of a tropical hypertrophic reservoir permanently stratified. Hydrobiologia. 2014; (522): 301-310.

[21] Angelier E. Ecologie des eaux courantes. Tec et Doc., Paris. 2000; 199.

[22] Nisbet M, Verneaux J. Composantes chimiques des eaux courantes. Discussion et proposition de classes en tant que bases d'interprétation des analyses chimiques. Annales de Limnologie, fasc. 1970; 2: 161-190.

[23] Villeneuve V, Légaré S, Painchaud J, Vincent W. Dynamique et modélisation de l'oxygène dissous en rivière. Université du Quebec-INRS-Eau, Terre et Environnement (INRS-ETE). Revue des sciences de l'eau, volume 19, n4. 2006; ISSN: 1718-8598.

[24] Dajoz R. Précis d'écologie. Dunod, Paris. 1982. 
[25] Banas D. et Lata J-C. Les phosphates. Université Paris-Sud ; Laboratoire d'Ecologie, Systématique et Evolution ; UMR 8079-CNRS/ENGREF/Univ. Paris-Sud ; Bât 362 ; F-91405 Orsay Cedex France. 2006; 2.

[26] Vannote RL, Minshall GW, Cummings KW, Sedell JR, Cushing CE. The River Continuum Concept. Canadian Journal of Fisheries and Aquatic Sciences. 1980; 37: 130-137.

[27] CCMRE (Conseil canadien des ministres des ressources et de l'environnement). Préparé par le groupe de travail sur les Recommandations canadiennes pour la qualité de l'eau. 1987.

[28] Rodier J, Legube B, Merlet N. L'analyse de l'eau. Dunod, 9e édition, Paris. 2009; 1579.

[29] Boust D, Fischer JC, Ouddane B, Petit F, Wartel M. Fer et manganèse: réactivités et recyclages. Presses de Cloître Imprimeurs ISBN 2-84433-028-2 Programme Seine-Aval ISBN 2-84433-022-3 / Dépôt légal 4e trimester. 1999; 4.

[30] Ndjouondo GP, Ngene JP, Ngoule CC, Kidik PMC, Ndjib RC, Dibong SD, Ndoutamia GT, Seid Ali M, Ngakou A. Etude comparative de la qualité physico-chimique des eaux de puits, de forages et de rivières consommées dans le bassin pétrolier de Doba au Tchad Maoudombaye . Larhyss Journal, ISSN 1112-3680, n²4. Décembre 2015; 193208.

[31] Priso RJ, Dibong SD, Tchinda-Metagne C, Taffouo V, Din N, Amougou A. Impacts des eaux polluées sur la croissance, les teneurs en chlorophylles et substances organiques dans les feuilles de deux Poaceae. Int. J. Biol. Chem. Sci. 2010; 4(4): 1122-1129.

[32] Ramade F. Eléments d'Ecologie: Ecologie appliquée. 6e édition, Dunod, Paris. 2005; 864.

[33] Haslam SM, Wolseley PA. River plants of Western Europe. The macrophytic vegetation of water courses of the European Economic Community. Cambridge Univ. 1987; 512.

[34] Diop NF. Intégration de la biodiversité d'eau douce dans le processus de développement en Afrique: Mobilisation de l'information et sites de démonstration. Projet de démonstration du bassin du fleuve Gambie. $2010 ; 48$.

[35] Saar A, Thiam A, Bâ AT. Macrophytes et groupements végétaux aquatiques et amphibies de la basse vallée du ferlo (sénégal). African Journal of Science and Technology. 2001; 2(1): 89- 97.

[36] Barendregt A, Bio AMF. Relevant variables to predict macrophyte communities in running waters. Ecological Modelling. 2003; 160(3): 205-217.

[37] Breugnot E, Dutartre A, Laplace-Treyture C, Haury J. Variabilité des peuplements de macrophytes aquatiques en grands cours d'eau : premiers résultats sur l’hydrosystème Adour-Garonne. Ingénieurs N³7. 2004; 37-50.

[38] Barbe J. Les végétaux aquatiques: Données biologiques et écologiques. Clés de détermination des macrophytes de France. Bull. fr. piscic. $57 \mathrm{n}^{\circ}$ spec. 1984; 42. 